\title{
SYNTHESIS AND NMR STRUCTURE DETERMINATION OF NEW LINEAR GERANYLPHENOLS BY DIRECT GERANYLATION OF ACTIVATED PHENOLS.
}

\author{
LAUTARO TABORGA ${ }^{a}$, ALEJANDRA VERGARA ${ }^{a}$, MARÍA JOSÉ FERNÁNDEZ ${ }^{a}$, MAURICIO OSORIO $^{a}$, \\ MARCELA CARVAJAL ${ }^{a}$, ALEJANDRO MADRID ${ }^{a}$, FRANCISCO MARILAF ${ }^{a}$, HÉCTOR CARRASCO ${ }^{b}$ AND LUIS \\ ESPINOZA CATALÁN ${ }^{a *}$.
}

\author{
${ }^{a}$ Departamento de Química, Universidad Técnica Federico Santa María, Valparaíso, Chile. \\ ${ }^{b}$ Departamento de Ciencias Químicas, Universidad Andrés Bello, Viña del Mar, Chile.
}

(Received: August 22, 2012 - Accepted: January 23, 2013)

\begin{abstract}
The known geranylhydroquinone 2, geranylorcinol 4 and the derivative (E)-4-(3,7-dimethylocta-2,6-dienyl)-5-methylbenzene-1,3-diol 5, were prepared by Electrophilic Aromatic Substitution $(E A S)$ reactions between the corresponding phenol derivatives containing electron-donor subtituents and geraniol using $\mathrm{BF}_{3} \times \mathrm{OEt}_{2}$ as a catalyst. In addition, spectroscopic NMR information for $\mathbf{4}$ and $\mathbf{5}$ is complemented. Furthermore, the new (E)-2-(3,7-dimethylocta-2,6-dienyl) benzene-1,3,5-triol (geranylphloroglucinol) 13, (E)-2-(3,7-dimethylocta-2,6-dienyl)-1,3,5-trimethoxybenzene 14, (E)-2-(3,7-dimethylocta-2,6-dienyl)-6methoxyphenol 15, (E)-3-(3,7-dimethylocta-2,6-dienyl)-2-methoxyphenol 16, (E)-5-(3,7-dimethylocta-2,6-dienyl)-2-methoxyphenol 17, $(E)$-4-(3,7-dimethylocta2,6-dienyl)benzene-1,3-diol 18, (E)-3-(3,7-dimethylocta-2,6-dienyl)benzene-1,2-diol 19, (E)-4-(3,7-dimethylocta-2,6-dienyl)-5-isopropyl-2-methylphenol 20, (E)-2-(3,7-dimethylocta-2,6-dienyl)-4-isopropyl-3-methylphenol 21, (E)-2-(3,7-dimethylocta-2,6-dienyl)-4-isopropyl-5-methylphenol 22, and(E)-2-tert-butyl-4(3,7-dimethylocta-2,6-dienyl)-5-methylphenol $\mathbf{2 3}$ were also prepared with this synthesis strategy. All the synthesized compounds were fully characterized and their structures were established by IR, MS and mainly NMR spectroscopic dates.
\end{abstract}

Keywords: Linear geranylphenols, synthesis, NMR spectroscopy.

\section{INTRODUCTION}

The subgroups of linear geranylquinones or geranylhydroquinones are represented by an important number of compounds, for example 2-geranylbenzoquinone (1) isolated from Ascindian Synoicum castellatum [1] and 2-geranylhydroquinone (2) isolated from tree Cordia alliodora [2], Phacelia crenulata [3-5], Aplidium antillense [6] and the tunicate Amaroucium multiplicatum [7]. Both natural products are present in higher plants, but also have been reported in marine urochordates [8].

2-geranylbenzoquinone (1) exhibits interesting biological activities such as toxicity against Gambusia affinis and Artemia salina, antimicrobial activity against Pseudomonas aeruginosa, Escherichia coli, Candida albicans, Micrococcus luteus and Bacillus subtilis [9]. Also the compound $\mathbf{1}$ has been reported as a potent skin sensitizer for guinea pigs, proving to be a fairly reliable indicator of allergenicity against human skin [3]. In addition, it has antimicrobial activity against Serratia marcescens, Morganella morganii, Proteus mirabilis, Klebsiella pneumoniae, Escherichia coli, Pseudomonas aeruginosa, Streptococcus fecalis and antimicrobial activity against methicillinresistant Staphylococcus aureus [9]. Cytotoxicity against mouse P388 cells and cytotoxicity against human $\mathrm{KB}$ cells has also been reported for this compound [6], as well as inhibition of soybean arachidonate 15-lipoxygenase and antioxidant activity in rat liver microsomes assessed as inhibition of lipid peroxide formation [7]. Furthermore, 2-geranylhydroquinone (2) has been synthesized as a drug and it has been reported to have some value as radioprotective and anti-cancer protective agents [10-11].

Additionally, the evaluation of Cancer-Preventive Activity and StructureActivity Relationships (SAR) of 3-demethylubiquinone Q2 (3), isolated from the Ascidian Aplidium glabrum [12], and the geranylhydroquinone synthetic analogues were informed. All the compounds tested were able to inhibit JB6 Cl41 cell transformation, to induce apoptosis, AP-1, and NF-KB activity, and to inhibit p53 activity [13]. On the other hand, the geranylorcinol derivatives 4 and 5 (figure 1) showed antimicrobial and antifungal activities [14-15].

The geranylmethoxyphenol 6 (isolated from Piper crassinervium Kunth) showed antioxidant activity [16], whereas the linear geranylmethoxyphenol/ acetates 7-9 (see figure 1), isolated from Phacelia ixodes [5], showed a biological activity which allows to repel and in some cases, to kill phytophagous insects and plant pathogens [17].

Recently, our research group reported the synthesis and in vitro cytotoxic activity against cells of PC-3 prostate cancer, MCF-7 and MDA-MB-231 breast carcinoma of compounds 1, 2 and some methoxylated geranylphenol derivatives in $\mu \mathrm{M}$ concentrations.

These compounds were obtained by Electrophilic Aromatic Substitution (EAS) reactions between geraniol and the phenols 1,4-hydroquinone and $p$-methoxyphenols using $\mathrm{BF}_{3} \cdot \mathrm{Et}_{2} \mathrm{O}$ as catalyst. [18] [19].

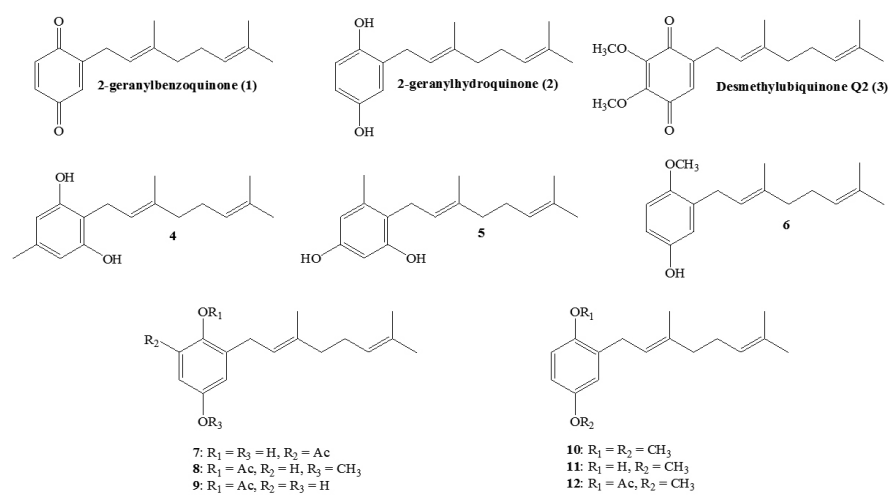

Figure 1.Structure of some active linear geranylquinone and geranylphenols.

On another hand, several factors highlight the urgent need for the development of new strategies for the control of phytopathogen fungus Botrytis cinerea and other plagues affecting important Chilean agricultural crops. They include the emergence of Botrytis strains resistant to fungicides, the high cost of chemical control and the limited availability of fungicides. In addition, it should be considered the strong worldwide trend towards sustainable development and environmentally friendly substances. Therefore, our interest is to gain a broader insight about the biological properties of these substances against plant pathogens which are important for the local national industry. On the basis of previously described and considering the structure -activity relationship with the derivatives 6-12, in this opportunity we report the synthesis of 2, 4-5 and the new 13-23 linear geranylmethoxyphenol derivatives (figure 2) by direct geranylation reactions of activated phenols, between geraniol and orcinol, phloroglucinol, guaiacol, resorcinol, catechol, carvacrol, 4-isopropyl3-methylphenoland 2-tert-butyl-5-methylphenol using $\mathrm{BF}_{3} \cdot \mathrm{Et}_{2} \mathrm{O}$ as catalyst. In addition, the structural determinations of these new eleven compounds were established by chemical and spectroscopic properties and the effect in the inhibition of the growth of $B$. cinerea will be informed later. 


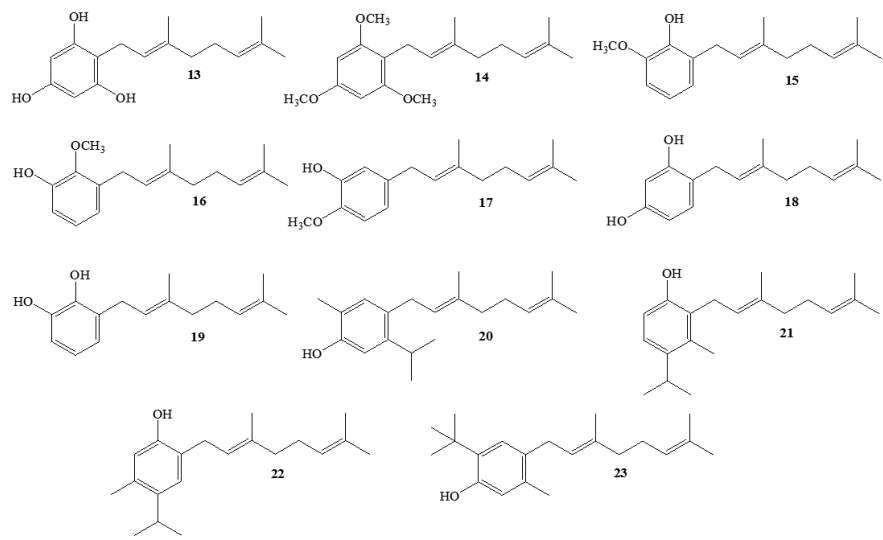

Figure 2.Structure of new linear geranylphenol derivatives.

\section{RESULTS AND DISCUSSION}

Our first objective was the preparation of compounds $\mathbf{2 , 4 - 5}$, using the coupling method previously described by us $[18,19]$ with geraniol and commercially available hydroquinone and orcinol, respectively. In this case, 2-geranylhydroquinone $\mathbf{2}$ was obtained with $28 \%$ yield, whereas the compounds 4 and $\mathbf{5}$ were obtained with $12.6 \%$ and $27.6 \%$ yields, respectively. The physical and spectroscopic properties of compounds 4 and 5 were consistent with those previously reported $[14,15]$. In addition, for the case of geranylorcinol structure derivatives, these were fully characterized by our research group, where the position of geranyl chain was established by selective 1D NOESY and 2D HMBC experiments, according to interactions shown in figure 3.

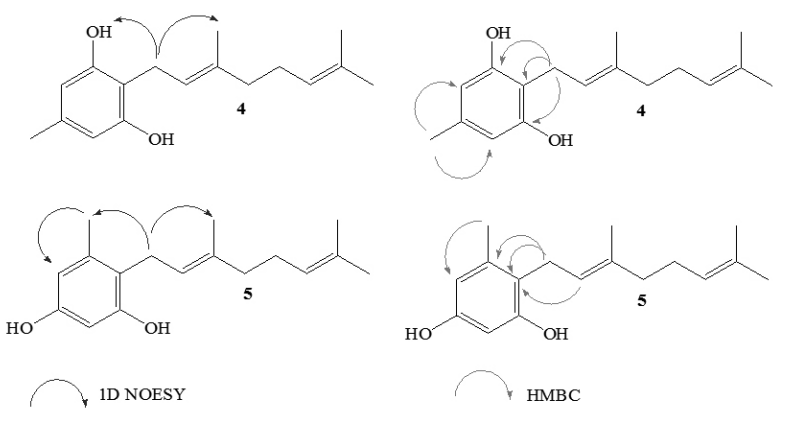

Figure 3. Observed correlations $1 \mathrm{D}$ NOESY and $2 \mathrm{D}{ }^{1} \mathrm{H}-{ }^{-13} \mathrm{C}$ HMBC in the NMR experiments for the compounds $\mathbf{4}$ and $\mathbf{5}$, which confirm the position and geometrical orientation of double bond in the geranyl chain.

The synthesis of compound $\mathbf{1 3}$ (geranylphloroglucinol proposed name by us in analogy with the name of geranylorcinol) was development by direct geranylation reactions between phloroglucinol (benzene-1,3,5-triol) and geraniol with a $4,2 \%$ yield. Later, the compound $\mathbf{1 3}$ was methylated with dimethylsulfate in acetone as was previously described by us for other compounds [18]. The trimethoxylated derivative $\mathbf{1 4}$ was obtained with a 98.5 $\%$ yield.These reactions are shown in scheme 1 .

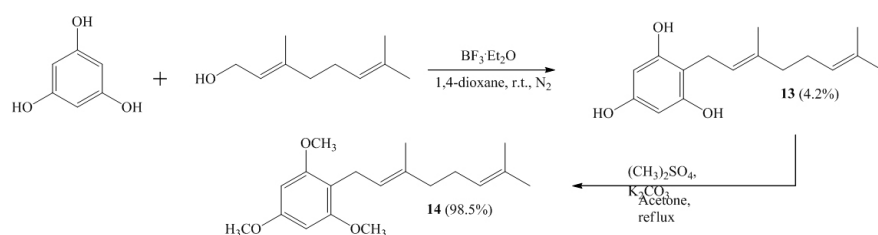

Scheme 1: Synthesis of geranylphloroglucinol 13 and their trimethoxylated derivative 14.

The determination of structure of $\mathbf{1 3}$ was mainly established by the NMR aromatic signal at $d_{\mathrm{H}}=5.93 \mathrm{ppm}$, where was observed a singlet for two hydrogen
H-4 and H-6, confirming the unique possibility of aromatic mono-substitution. Additionally, the signal at $d_{\mathrm{H}}=3.30 \mathrm{ppm}$ to assigned at $\mathrm{H}-2^{\prime}(\mathrm{d}, J=6.9 \mathrm{~Hz}$, $2 \mathrm{H})$ shows ${ }^{3} J_{\mathrm{H}-\mathrm{C}}$ coupling with C-1 and C-3 $\left(d_{\mathrm{C}}=155.7 \mathrm{ppm}\right)$ and ${ }^{2} J_{\mathrm{H}-\mathrm{C}}$ coupling with C-2 $\left(d_{C}=106.3 \mathrm{ppm}\right)$, these $\mathrm{HMBC}$ correlations are shown in figure 4 . In order to establish the $E$ geometry in double bond position at C-2'-C-3' of the geranyl chain, selective 1D NOESY NMR experiments were registered for the compound 13. These correlations are shown in figure 4, where the most important of those correspond to the correlation observed between the H-2, and the hydrogens of methyl group in C-3' position. For the derivative 14, in ${ }^{1} \mathrm{H}$ NMR spectra the two singlet signal at $d_{\mathrm{H}}=3.92 \mathrm{ppm}\left(3 \mathrm{H}, \mathrm{OCH}_{3}\right)$ and $d_{\mathrm{H}}=$ $3.79 \mathrm{ppm}\left(6 \mathrm{H}, 2 \times \mathrm{OCH}_{3}\right)$ confirm the presence of trimethoxylated derivative.
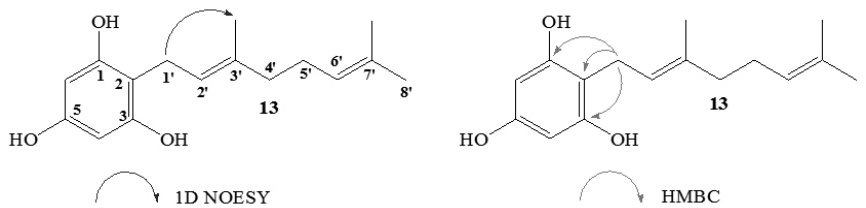

Figure 4. Observed correlations 1D NOESY and $2 \mathrm{D}{ }^{1} \mathrm{H}^{-13} \mathrm{C}$ HMBC in the NMR experiments for the compound 13, which confirm the position and geometrical orientation of double bond in the geranyl chain.

The following step consisted in the preparation of compound $\mathbf{1 5}$. Nevertheless, the regio-isomers $\mathbf{1 6}$ and $\mathbf{1 7}$ also were obtained according to scheme 2 .

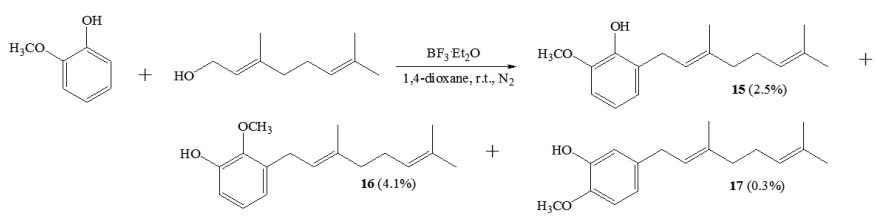

Scheme 2: Synthesis of derivatives $\mathbf{1 5}, \mathbf{1 6}$ and $\mathbf{1 7}$ by direct geranylation between geraniol and guaiacol (2-methoxyphenol) catalyzed by $\mathrm{BF}_{3} \mathrm{Et}_{2} \mathrm{O}$.

The substitution position of geranyl chain in aromatic ring was established in base at NMR data spectra, mainly from the 2D HMBC and selective 1D NOESY correlations. For the compound 15, the signal at $d_{\mathrm{H}}=3.39 \mathrm{ppm}(\mathrm{d}, J$ $=6.6 \mathrm{~Hz}, 2 \mathrm{H}, \mathrm{H}-1$ ' $)$ showed ${ }^{3} J_{\mathrm{H}-\mathrm{C}}$ coupling with $\mathrm{C}-1\left(d_{\mathrm{C}}=143.3 \mathrm{ppm}\right)$ and ${ }^{2} J_{\mathrm{H}-\mathrm{C}}$ coupling with $\mathrm{C}-2\left(d_{\mathrm{C}}=127.5 \mathrm{ppm}\right)$, while other HMBC correlations are shown in figure 5 . In the compound 16, the signal at $d_{\mathrm{H}}=3.29 \mathrm{ppm}(\mathrm{d}, J=7.2 \mathrm{~Hz}$, $\left.2 \mathrm{H}, \mathrm{H}-1^{\prime}\right)$ showed ${ }^{3} J_{\mathrm{H}-\mathrm{C}}$ coupling with $\mathrm{C}-2\left(d_{\mathrm{C}}=146.4 \mathrm{ppm}\right)$ and ${ }^{2} J_{\mathrm{H}-\mathrm{C}}$ coupling with C-3 $(d=133.7 \mathrm{ppm})$, additionally, other HMBC correlations are shown in figure 5. In addition, for the compound $\mathbf{1 7}$ the signal at $d_{\mathrm{H}}=3.26 \mathrm{ppm}(\mathrm{d}, J=$ $7.2 \mathrm{~Hz}, 2 \mathrm{H}, \mathrm{H}-1$ ') showed ${ }^{3} J_{\mathrm{HC}}$ coupling with $\mathrm{C}-6\left(d_{\mathrm{C}}=114.6 \mathrm{ppm}\right)$, with C-4 $\left(d_{\mathrm{C}}=119.5 \mathrm{ppm}\right)$ and ${ }^{2} J_{\mathrm{H}-\mathrm{C}}$ coupling with $\mathrm{C}-5\left(d_{\mathrm{C}}=135.2 \mathrm{ppm}\right)$, additionally, other HMBC correlations are shown in figure 5 .

In order to establish the $E$ geometry in double bond position at C-2'-C-3' of the geranyl chain, selective 1D NOESY NMR experiments were registered for the compounds $\mathbf{1 5}, \mathbf{1 6}$ and $\mathbf{1 7}$. These correlations are shown in figure 5, where the most important of those correspond to the observed between the $\mathrm{H}-2^{\prime}$ of geranyl chain with the hydrogens of the $\mathrm{CH}_{3}-\mathrm{C} 3$ 'and between some substituents in aromatic nucleus.

On the other hand, the direct geranylation between resorcinol and geraniol produced the compound $\mathbf{1 8}$ with $11.9 \%$ yield. The structure and pattern of the aromatic monosubstitution of this compound were established from NMR data spectra. In ${ }^{1} \mathrm{H}$ NMR spectrum, the signals at $d_{\mathrm{H}}=6.92 \mathrm{ppm}(\mathrm{d}, J=8.8 \mathrm{~Hz}, 1 \mathrm{H}$, $\mathrm{H}-5)$ and $d_{\mathrm{H}}=6.37-6.35 \mathrm{ppm}(\mathrm{m}, 2 \mathrm{H}, \mathrm{H}-2$ and $\mathrm{H}-4)$ confirm the presence of a tri-substituted aromatic system. The position of geranyl chain substitution in the aromatic nucleus was determined from the $2 \mathrm{D} \mathrm{HMBC}$ and selective 1D NOESY techniques. The signal at $d_{\mathrm{H}}=3.27 \mathrm{ppm}\left(\mathrm{d}, J=7.2 \mathrm{~Hz}, 2 \mathrm{H}, \mathrm{H}-1^{\prime}\right)$ showed heteronuclear ${ }^{3} J_{\mathrm{HC}}$ coupling with C-3 $\left(d_{\mathrm{C}}=154.8 \mathrm{ppm}\right)$ and C-5 $\left(d_{\mathrm{C}}\right.$ $=130.3 \mathrm{ppm})$ and ${ }^{2} J_{\mathrm{H}-\mathrm{C}} \mathrm{Coupling}$ with $\mathrm{C}-4\left(d_{\mathrm{C}}=124.0 \mathrm{ppm}\right)$. Other HMBC correlations are shown in the figure 6 . Additionally, the signal assigned at $\mathrm{H}-1$ ( $3.27 \mathrm{ppm}, \mathrm{d}, J=7.2 \mathrm{~Hz}, 2 \mathrm{H}$ ) showed long range NOE interaction with aromatic $\mathrm{H}-5(6.92 \mathrm{ppm}, \mathrm{d}, J=8.8 \mathrm{~Hz}, 1 \mathrm{H})$ confirming the geranyl chain position and $\mathrm{CH}_{3}-\mathrm{C}^{\prime}(1.72 \mathrm{ppm}, \mathrm{s}, 3 \mathrm{H})$ that indicate the geometrical orientation of double bond in $\mathrm{C}^{2}-\mathrm{C} 3$ ', as shown in figure 6. 

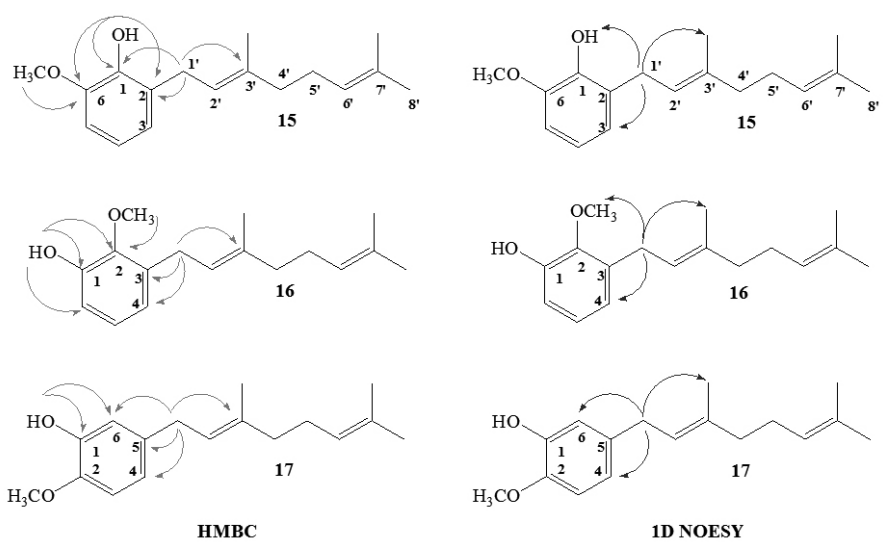

Figure 5. Main 2D HMBC and 1D NOESY observed correlations that allowed differentiate and determine the regio-isomer structures 15, 16 and 17.
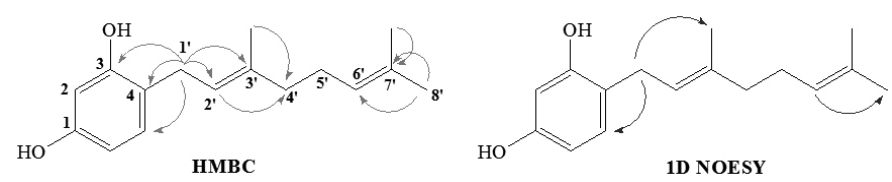

Figure 6. $2 \mathrm{D} \quad{ }^{1} \mathrm{H}-{ }^{13} \mathrm{C}$ HMBC and $1 \mathrm{D}$ NOESY observed correlations in the NMR experiments for the compound 18, which confirm the aromatic substitution position and geometrical orientation of double bond in the geranyl chain.

For the synthesis of compound 19, pyrocatechol and geraniol were used. In this opportunity, the geranyl chain was substituted in ortho position respect to hydroxyl group at the aromatic nucleus; as in the previous cases, the structure of compound 19 and geranyl chain position were confirmed by NMR data spectra. In ${ }^{1} \mathrm{H}$ NMR spectrum the signals at $d_{\mathrm{H}}=6.79-6.72(\mathrm{~m}, 2 \mathrm{H}, \mathrm{H}-5$ and $\mathrm{H}-6)$ and $6.66(\mathrm{~d}, J=7.0 \mathrm{~Hz}, 1 \mathrm{H}, \mathrm{H}-4) \mathrm{ppm}$ confirm the presence of a tri-substituted aromatic system. From 2D HMBC spectrum, the signal at $d_{\mathrm{H}}=$ $3.37 \mathrm{ppm}\left(\mathrm{d}, J=7.1 \mathrm{~Hz}, 2 \mathrm{H}, \mathrm{H}-1^{\prime}\right)$ showed heteronuclear ${ }^{3} J_{\mathrm{HC}}$ coupling with C-2 $\left(d_{\mathrm{C}}=141.9 \mathrm{ppm}\right)$ and C-4 $\left(d_{\mathrm{C}}=121.4 \mathrm{ppm}\right)$ and ${ }^{2} J_{\mathrm{H}-\mathrm{C}}$ coupling with C-3 $\left(d_{\mathrm{C}}=127.4 \mathrm{ppm}\right)$. HMBC correlations are shown in the figure 7. Additionally, the signal to assigned at $\mathrm{H}-1^{\prime}(3.37 \mathrm{ppm}, \mathrm{d}, J=7.1 \mathrm{~Hz}, 2 \mathrm{H})$ showed long range NOE interaction with aromatic H-4 $(6.66 \mathrm{ppm}, \mathrm{d}, J=7.0 \mathrm{~Hz}, 1 \mathrm{H})$ confirming the geranyl chain position and with single signal $\mathrm{CH}_{3}-\mathrm{C}^{\prime}$ ' $(1.78 \mathrm{ppm}, \mathrm{s}, 3 \mathrm{H})$ that indicate the geometrical orientation of double bond in $\mathrm{C}^{2}$ '-C3', as shown in figure 7.
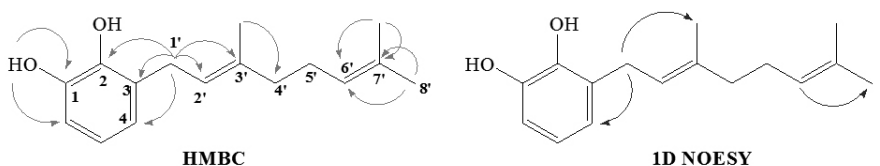

Figure 7. Principal 2D ${ }^{1} \mathrm{H}_{-}{ }^{13} \mathrm{C}$ HMBC and $1 \mathrm{D}$ NOESY observed correlations in the NMR experiments for the compound 19, these confirm the aromatic substitution position and geometrical orientation of double bond in the geranyl chain.

Later, the compounds 20, 21, 22 and $\mathbf{2 3}$ were obtained by direct geranylation between carvacrol, 4-i-propyl-3-methylphenol, 2-t-butyl-5methylphenol and geraniol under identical conditions for the three cases. Nevertheless, in the latter case, ethyl ether was used as dissolvent instead of dioxane (to see scheme 3). These compounds were obtained with $21.7 \%, 4.2$ $\%$ and $17.7 \%$ yield, respectively. In addition, the $\mathbf{2 1 - 2 2}$ mixture was obtained with a $25.2 \%$ yield, when the 4-i-propyl-3-methylphenol reacted with geraniol according to the scheme 3 .

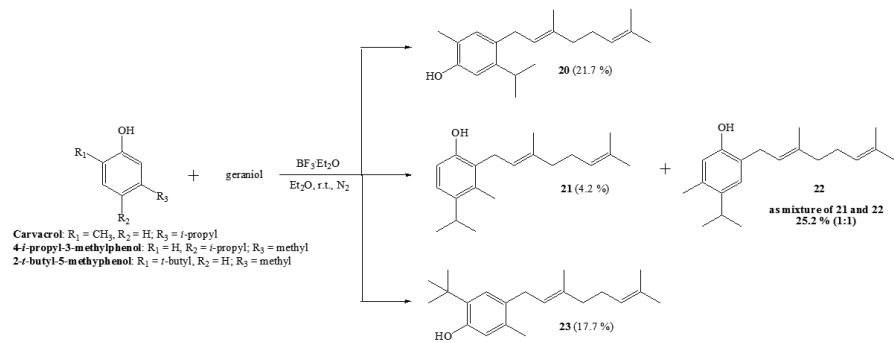

Scheme 3: Synthetic route for the obtaining of derivatives 20-23 by direct geranylation reaction between, carvacrol, 4-i-propil-3-methylphenol and 2-t-butil-5-methylphenol and geraniol in $\mathrm{Et}_{2} \mathrm{O}$ catalyzed by $\mathrm{BF}_{3} \cdot \mathrm{Et}_{2} \mathrm{O}$.

The structural determination of these compounds was mainly established by NMR data spectra. Thus, for compound $\mathbf{2 0}$, the signals at $d_{\mathrm{H}}=6.88 \mathrm{ppm}$ (s, $1 \mathrm{H}, \mathrm{H}-3)$ and $6.69 \mathrm{ppm}(\mathrm{s}, 1 \mathrm{H}, \mathrm{H}-6)$ indicate the aromatic substitution pattern, confirming that the geranyl fragment was incorporated in para orientation with respect to hydroxyl group. Additionally, ${ }^{3} J_{\mathrm{HC}} \mathrm{HMBC}$ correlations were observed between H-1' $\left(d_{\mathrm{H}}=3.27 \mathrm{ppm}, \mathrm{d}, J=6.8 \mathrm{~Hz}\right)$ with $\mathrm{C}-3\left(d_{\mathrm{C}}=131.9\right.$ $\mathrm{ppm}), \mathrm{C}-5\left(d_{\mathrm{C}}=146.1 \mathrm{ppm}\right)$ and C-3' $\left(d_{\mathrm{C}}=135.3 \mathrm{ppm}\right)$ on the other hand, ${ }^{2} J_{\mathrm{H}-\mathrm{C}}$ correlation with C-4 $\left(d_{\mathrm{C}}=130.8 \mathrm{ppm}\right)$ and C-2' $\left(d_{\mathrm{C}}=124.1 \mathrm{ppm}\right)$ also were observed (to see figure 8). Additionally, long range interactions (NOE) between $\mathrm{H}-1^{\prime}$ ' with $\mathrm{H}-3\left(d_{\mathrm{H}}=6.88 \mathrm{ppm}, \mathrm{s}, 1 \mathrm{H}\right)$ and $\mathrm{CH}_{3}-\mathrm{C}-3^{\prime}\left(d_{\mathrm{H}}=1.71 \mathrm{ppm}\right.$, $\mathrm{s}, 3 \mathrm{H})$ were observed which confirmed the geometrical $E$ orientations around of double bond $\mathrm{C} 2$ '-C3' and geranyl fragment position in the aromatic nuclei (to see figure 8)
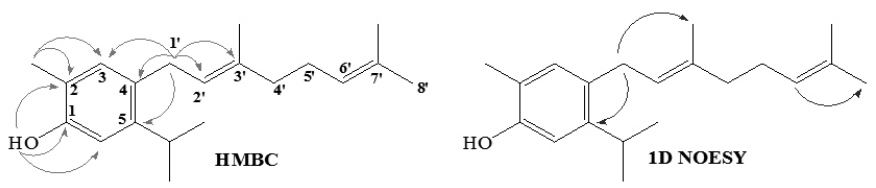

Figure 8. Main 2D 1H-13C HMBC and 1D NOESY observed correlations in the NMR experiments for the compound 20, these confirm the aromatic substitution position and geometrical orientation of double bond in the geranyl chain.

When 4-i-propil-3-methylphenol was reacted with geraniol catalyzed by $\mathrm{BF} \cdot \mathrm{Et}_{2} \mathrm{O}$ under ethereal solution, the compounds $\mathbf{2 1}$ and $\mathbf{2 2}$ were obtained. After work-up and posterior flash conventional C.C. purification and separation, only the compound 21 was accessible in pure form with a $4.2 \%$ yield. However, the mixture of compounds 21-22 was mainly obtained with a $25.2 \%$ yield. The proportion of compounds $\mathbf{2 1 / 2 2}=\mathbf{1 : 1}$ present in the mixture was determined from ${ }^{1} \mathrm{H}$ NMR spectrum, considering the average values of integration area for signal assigned to the aromatic hydrogens. $\mathrm{H}-1^{\prime}$ and $\mathrm{CH}\left(\mathrm{CH}_{3}\right)_{2}$ signals were clearly identified in the ${ }^{1} \mathrm{H}$ NMR spectrum onto the mixture.

The structure of compound $\mathbf{2 1}$ was easily identified due to the pattern of aromatic substitution shown in the spectrum of ${ }^{1} \mathrm{H}$ RMN. Two doublet signal at $d_{\mathrm{H}}=7.01 \mathrm{ppm}(\mathrm{d}, J=8.4 \mathrm{~Hz}, 1 \mathrm{H}, \mathrm{H}-5)$ and $d_{\mathrm{H}}=6.67 \mathrm{ppm}(\mathrm{d}, J=8.4 \mathrm{~Hz}$, $1 \mathrm{H}, \mathrm{H}-6)$ confirmed that the geranyl chain was to incorporated in ortho position with respect to hydroxyl group, specifically, in C-2. Additionally, ${ }^{3} J_{\mathrm{H}-\mathrm{C}} \mathrm{HMBC}$ correlations were observed between $\mathrm{H}-1$ ' $\left(d_{\mathrm{H}}=3.41 \mathrm{ppm}, \mathrm{d}, J=6.6 \mathrm{~Hz}\right)$ with $\mathrm{C}-1\left(d_{\mathrm{C}}=151.1 \mathrm{ppm}\right)$ and C-3 $\left(d_{\mathrm{C}}=131.7 \mathrm{ppm}\right)$. Additionally, ${ }^{2} J_{\mathrm{H}-\mathrm{C}}$ correlation with C-2 $\left(d_{\mathrm{C}}=125.9 \mathrm{ppm}\right)$ and C-2' $\left(d_{\mathrm{C}}=122.1 \mathrm{ppm}\right)$ were also observed (to see figure 9).

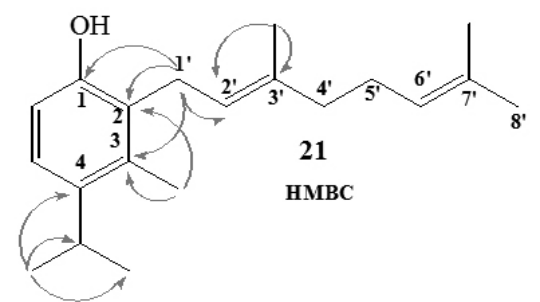

Figure 9. Main $2 \mathrm{D}{ }^{1} \mathrm{H}^{-13} \mathrm{C}$ HMBC observed correlations in the NMR spectrum for the compound 21, which confirm the aromatic substitution position of the geranyl chain. 
The structural assignation of compound $\mathbf{2 2}$ was established by comparison from ${ }^{1} \mathrm{H}$ NMR spectrum of pure 21 with the mixture 21/22. Thus, in the ${ }^{1} \mathrm{H}$ NMR spectrum of mixture the signals at $d_{\mathrm{H}}=6.96 \mathrm{ppm}(\mathrm{s}, 1 \mathrm{H})$ and $6.62 \mathrm{ppm}$ (s, $1 \mathrm{H}$ ) were assigned to the $\mathrm{H}-3$ and $\mathrm{H}-6$, respectively, indicating the aromatic substitution pattern. Additionally, the ${ }^{1} \mathrm{H}$ NMR signal at $d_{\mathrm{H}}=5.04 \mathrm{ppm}(\mathrm{s}, 1 \mathrm{H})$;
$3.35 \mathrm{ppm}(\mathrm{d}, J=7.1 \mathrm{~Hz}, 2 \mathrm{H}) ; 3.06 \mathrm{ppm}$ (sept. $J=6.8 \mathrm{~Hz}, 1 \mathrm{H}) ; 2.27 \mathrm{ppm}(\mathrm{s}$, $3 \mathrm{H}) ; 1.79 \mathrm{ppm}(\mathrm{s}, 3 \mathrm{H}) ; 1.70 \mathrm{ppm}(\mathrm{s}, 3 \mathrm{H}) ; 1.61 \mathrm{ppm}(\mathrm{s}, 3 \mathrm{H})$ and $1.25 \mathrm{ppm}(\mathrm{d}, J$ $=6.8 \mathrm{~Hz} ; 6 \mathrm{H})$ were assigned to the $\mathrm{OH}, \mathrm{H}-1, \mathrm{CH}\left(\mathrm{CH}_{3}\right)_{2}, \mathrm{CH}_{3}-\mathrm{Ar}, \mathrm{CH}_{3}-\mathrm{C} 3$, $\mathrm{CH}_{3}-8, \mathrm{CH}_{3}-\mathrm{C} 7$, and $\left(\mathrm{C}_{3}\right)_{2} \mathrm{CH}$ respectively, as shown in Figure 10 .

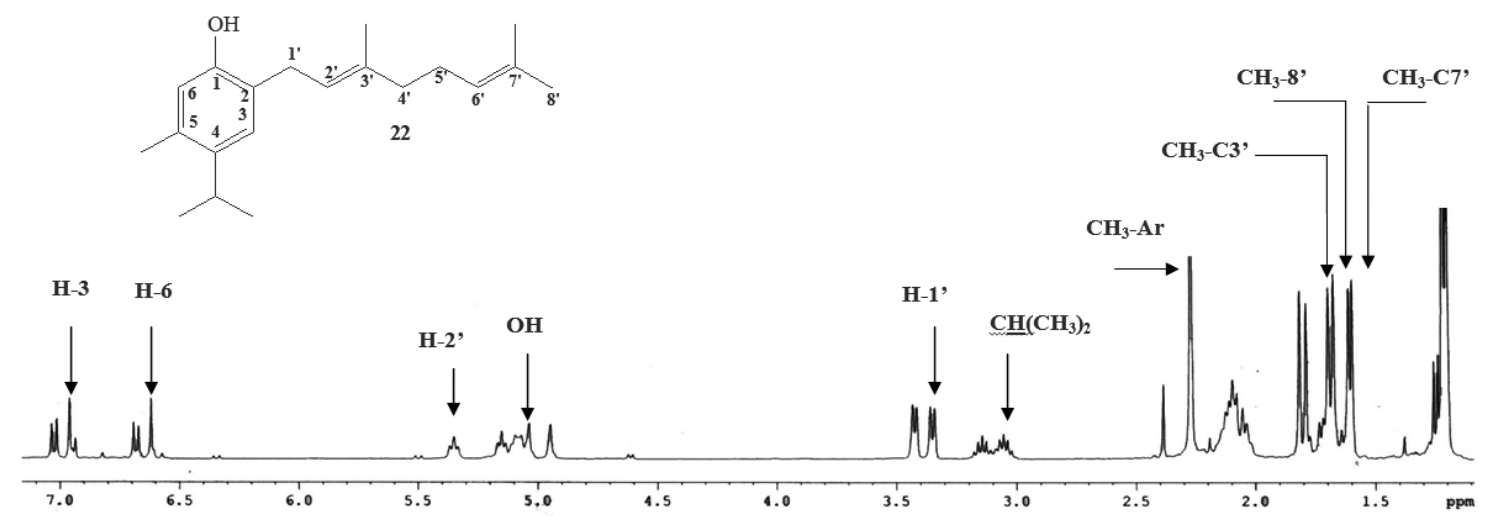

Figure 10. ${ }^{1}$ HNMR spectrum of the mixture compounds $\mathbf{2 1 / 2 2}$ and identification of the signals corresponding to the compound 22.

The structure of compound 22 was unequivocally assigned from 2D HSQC and HMBC spectra data of the mixture of compounds 21/22. Thus, for compound 22, the signals at $d_{\mathrm{H}}=3.35 \mathrm{ppm}(\mathrm{d}, J=7.1 \mathrm{~Hz}, 2 \mathrm{H}, \mathrm{H}-1$ ' $)$ showed ${ }^{3} J_{\mathrm{H}-\mathrm{C}} \mathrm{HMBC}$ correlations with $\mathrm{C}-1\left(d_{\mathrm{C}}=151.9 \mathrm{ppm}\right), \mathrm{C}-3\left(d_{\mathrm{C}}=126.3 \mathrm{ppm}\right)$ and $\mathrm{C}-3^{\mathrm{H}-\mathrm{C}}\left(d_{\mathrm{C}}=138.1 \mathrm{ppm}\right)$ and $^{2} J_{\mathrm{H}-\mathrm{C}}$ correlation with C-2 $\left(d_{\mathrm{C}}=123.8 \mathrm{ppm}\right)$ and C-2' $\left(d_{\mathrm{C}}=122.2 \mathrm{ppm}\right)$ also were observed. In addition other ${ }^{3} J_{\mathrm{H}-\mathrm{C}}$ and ${ }^{2} J_{\mathrm{H}-\mathrm{C}} \mathrm{HMBC}$ correlations are shown in figure 11.

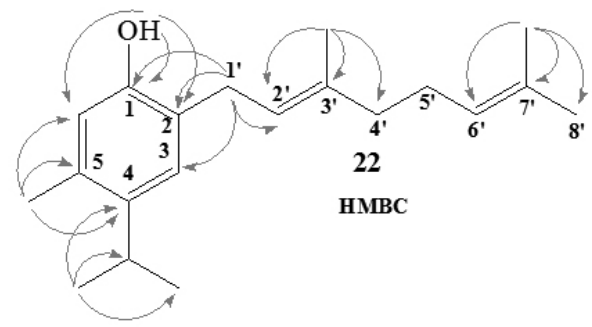

Figure 11. Major $2 \mathrm{D}{ }^{1} \mathrm{H}-{ }^{13} \mathrm{C}$ HMBC observed correlations in the NMR spectrum for the compound 22

On the other hand, from the 1D selective NOE NMR experiments was possible to determinate the long range interactions between the $\mathrm{H}-1$ ' with aromatic $\mathrm{H}-3$, olefinic $\mathrm{H}-2$ ', $\mathrm{OH}$ and $\mathrm{CH}_{3}-\mathrm{C} 3$ '. In addition to this information, was possible to confirm the geometric orientation around the $\mathrm{C} 2$ '- $\mathrm{C} 3$ ' double bond. These interactions are shown in Figure 12.

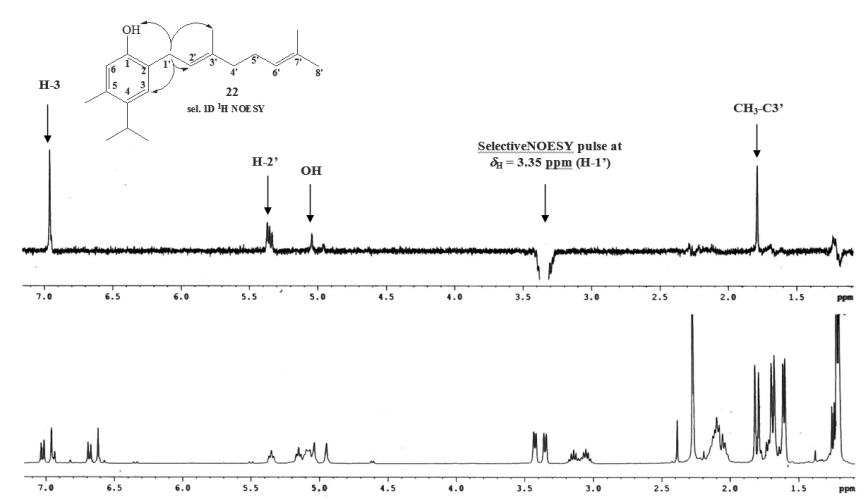

Figure 12. Bottom: normal ${ }^{1} \mathrm{H}-\mathrm{NMR}$ spectrum of mixture 21/22; Top: selective gs 1D NOESY irradiation at $=3.35 \mathrm{ppm}$ for compound $\mathbf{2 2}$ in the mixture, which long-range interactions can clearly be seen between $\mathrm{H}-1$ ' with $\mathrm{H}-3, \mathrm{OH}, \mathrm{H}-2$ ' and $\mathrm{CH}_{3}-\mathrm{C} 3$ '.

\section{EXPERIMENTAL}

General

Unless otherwise stated, all chemical reagents purchased (Merck or Aldrich) were of the highest commercially available purity and were used without previous purification. IR spectra were recorded as thin films in a FT-IR Nicolet 6700 spectrometer and frequencies are reported in $\mathrm{cm}^{-1}$. Low resolution mass spectra were recorded on an Agilent 5973 spectrometer at $70 \mathrm{eV}$ ionising voltage in a DB- $5 \mathrm{~m}, 30 \mathrm{~m} \times 0.25 \mathrm{~mm} \times 0.25$ um column, and dates are given as $\mathrm{m} / \mathrm{z}$ (\% rel. int.). ${ }^{1} \mathrm{H},{ }^{13} \mathrm{C},{ }^{13} \mathrm{C}$ DEPT-135, sel. gs $1 \mathrm{D}{ }^{1} \mathrm{H}$ NOESY, gs $2 \mathrm{D}$ HSQC and $g s$ 2D HMBC spectra were recorded in $\mathrm{CDCl}_{3}$ solutions and are referenced to the residual peaks of $\mathrm{CHCl}_{3}$ at $\delta=7.26 \mathrm{ppm}$ and $\delta=77.0 \mathrm{ppm}$ for ${ }^{1} \mathrm{H}$ and ${ }^{13} \mathrm{C}$, respectively, on a Bruker Avance 400 Digital NMR spectrometer, operating at $400.1 \mathrm{MHz}$ for $1 \mathrm{H}$ and $100.6 \mathrm{MHz}$ for ${ }^{13} \mathrm{C}$. For selective 1D NOESY experiment the selnogp. 3 with Z-PFG pulse program was used, obtained from Bruker Library and optimizedparameter at $\mathrm{ns}=32, \mathrm{ds}=4, \mathrm{~d} 1=2.0 \mathrm{sec}, \mathrm{TD}=$ $16 \mathrm{k}, \mathrm{sp} 2=73.0 \mathrm{~dB}, \mathrm{p} 12=80 \mathrm{msec}, \mathrm{d} 8=600 \mathrm{~ms}$, and gradient ratios: gpz $3=40$, gpz4 $=-40$. For gs $2 \mathrm{D}$ HSQC experiment invigpph pulse program was used and optimized parameter at $\mathrm{ns}=4, \mathrm{ds}=16, \mathrm{~d} 1=1.0 \mathrm{sec}, \mathrm{TD}=1 \mathrm{k}, \mathrm{p} 16=1.0 \mathrm{msec}$, $\mathrm{d} 16=500 \mathrm{msec}$, gradient ratios: gpz1 $=80, \mathrm{gpz} 2=30$ and gpz3 $=20.1$. For $g s$ 2D HMBC experiment invi4gplplrndqf with ${ }^{1} J_{\mathrm{HC}}$ filter (low-pass J-filter) pulse program was used and optimized parameter at $\mathrm{ns}=4, \mathrm{ds}=16, \mathrm{~d} 1=1.0 \mathrm{sec}$, TD $=1 \mathrm{k}, \mathrm{p} 16=1.0 \mathrm{msec}, \mathrm{d} 16=500 \mathrm{msec}$, gradient ratios: $\mathrm{gpz} 1=50, \mathrm{gpz} 2=30$ and gpz3 $=40.1$. Chemical shifts are reported in $\delta$ ppm and coupling constants $(J)$ are given in Hz. Silica gel (Merck 200-300 mesh) was used for C.C. and silica gel plates HF-254 for TLC. TLC spots were detected by heating after spraying with $25 \% \mathrm{H}_{2} \mathrm{SO}_{4}$ in $\mathrm{H}_{2} \mathrm{O}$.

(E)-2-(3,7-dimethylocta-2,6-dienyl)benzene-1,4-diol (1,4-geranylhydroquinone) 2

To a solution of 1,4-hydroquinone $(0,601 \mathrm{~g}, 5,5 \mathrm{mmol})$ and geraniol $(0,8$ $\mathrm{g}, 5,5 \mathrm{mmol})$ in 1,4-dioxane $(30 \mathrm{~mL}) \mathrm{BF}_{3} \mathrm{OEt}_{2}(0,23 \mathrm{~g}, 1.6 \mathrm{mmol})$ was slowly added dropwise with stirring at room temperature and under a $\mathrm{N}_{2}$ atmosphere, After the addition was completed, the stirring was continued overnight. When the end of the reaction was verified by TLC, the mixture was poured onto crushed ice (app. $30 \mathrm{~g})$ and it was extracted with diethyl ether $(3 \times 30 \mathrm{~mL})$. Then the ethereal layer was washed with $5 \% \mathrm{NaHCO}_{3}(30 \mathrm{~mL})$, water $(2 \times 15$ $\mathrm{mL}$ ), dried over $\mathrm{Na}_{2} \mathrm{SO}_{4}$, filtered and the solvent was evaporated under reduced pressure. The crude was redissolved in $\mathrm{CH}_{2} \mathrm{Cl}_{2}(5 \mathrm{~mL})$ and chromatographed on silicagel with petroleum ether/EtOAc mixtures of increasing polarity $(19.8: 0.2 \rightarrow 13.0: 7.0)$ to obtain the title compound as a brownish oil 0.373 g, 28\%). Spectroscopic data of compound 2 were consistent with those of literature.

(E)-2-(3,7-dimethylocta-2,6-dienyl)-5-methylbenzene-1,3-diol 4 and (E)4-(3,7-dimethylocta-2,6-dienyl)-5-methylbenzene-1,3-diol 5

To a solution of 5-methylbenzene-1,3-diol $(1,21 \mathrm{~g}, 9,8 \mathrm{mmol})$ and $\mathrm{BF}_{3}$. OEt $_{2}(1.4 \mathrm{~g}, 9.8 \mathrm{mmol})$ in freshly distilled 1,4-dioxane $(5 \mathrm{~mL})$ was slowly added dropwise, with stirring at room temperature and under a $\mathrm{N}_{2}$ atmosphere, 
a solution of geraniol $(1.5 \mathrm{~g}, 9.8 \mathrm{mmol})$ in 1,4-dioxane $(5 \mathrm{~mL})$. After the addition was complete, the stirring was continued overnight. When the end of the reaction was verified by TLC, the mixture was poured onto crushed ice (app. $30 \mathrm{~g})$ and it was extracted with diethyl ether $(3 \times 30 \mathrm{~mL})$. Then, the ethereal layer was washed with $5 \% \mathrm{NaHCO}_{3}(30 \mathrm{~mL})$, water $(2 \times 20 \mathrm{~mL})$, dried over $\mathrm{Na}_{2} \mathrm{SO}_{4}$, filtered and the solvent was evaporated under reduced pressure. The crude was redissolved in $\mathrm{CH}_{2} \mathrm{Cl}_{2}(5 \mathrm{~mL})$ and the mixture was subjected to silica gel flash column chromatography with petroleum ether/EtOAc mixtures of increasing polarity $(19.8: 0.2 \rightarrow 0.2: 19.8)$ as the mobile phase. Two fractions were obtained. Fraction I: $0.320 \mathrm{~g}(12.6 \%$ yields $)$ of viscous brownish oil compound 4. ${ }^{1} \mathrm{H}$ NMR: 6.26 (s, 1H, H-6); 6.22 (s, 2H, H-2); 5.60 (brs, $2 \mathrm{H}$ $\mathrm{OH}) ; 5.13\left(\mathrm{t}, J=6.8 \mathrm{~Hz}, 1 \mathrm{H}, \mathrm{H}-2^{\prime}\right) ; 5.05(\mathrm{t}, J=6.7 \mathrm{~Hz}, 1 \mathrm{H}, \mathrm{H}-6$ '); 3.28 (d, $J$ $=6.7 \mathrm{~Hz}, 2 \mathrm{H}, \mathrm{H}-1^{\prime}$ ); 2.21 (s, 3H, CH -Ar); 2.09-2.06 (m, 2H, H-5'); 2.04-2.00 (m, 2H, H-4'); 1.78 (s, 3H, CH -3'); 1.67 (s, 3H, H-8'); 1.60 (s, 3H, $\left.\mathrm{CH}_{3}-\mathrm{C} 7^{\prime}\right)$; ${ }^{13}$ C NMR: 155.2 (C-3); 154.1 (C-1); 138.6 (C-5); 137.2 (C-3'); 131.8 (C-7'); 123.9 (C-6'); 122.2 (C-2'); 118.1 (C-4); 109.7 (C-6); 101.0 (C-2); 39.6 (C$\left.4^{\prime}\right) ; 26.4$ (C-5'); 25.6 (C-8'); 25.0 (C-1'); 20.0 ( $\left.\mathrm{CH}_{3}-\mathrm{Ar}\right) ; 17.6\left(\mathrm{CH}_{3}-\mathrm{C}^{\prime}\right)$; $16.1\left(\mathrm{CH}_{3}-\mathrm{C} 3\right.$ '); IR $\left(\mathrm{cm}^{-1}\right): 3393,2975,2925,2859,1602 ; \mathrm{MS}(\mathrm{m} / \mathrm{z}, \%): \mathrm{M}^{+}$ 260 (21.7), 191 (26.9), 177 (13.9), 137 (100), 123 (10.5). Fraction II: 0.704 g (27.6\% yields) of viscous yellow oil, compound 5. ${ }^{1} \mathrm{H}$ NMR: $6.26(\mathrm{~s}, 1 \mathrm{H}$, $\mathrm{H}-6) ; 6.22$ (s, 2H, H-2); 5.60 (brs, 2H, OH); 5.13 (t, $J=6.8 \mathrm{~Hz}, 1 \mathrm{H}, \mathrm{H}-2$ ') $5.05\left(\mathrm{t}, J=6.7 \mathrm{~Hz}, 1 \mathrm{H}, \mathrm{H}-6{ }^{\prime}\right) ; 3.28\left(\mathrm{~d}, J=6.7 \mathrm{~Hz}, 2 \mathrm{H}, \mathrm{H}-1^{\prime}\right) ; 2.21$ (s, 3H, CH Ar); 2.09-2.06 (m, 2H, H-5'); 2.04-2.00 (m, 2H, H-4'); 1.78 (s, 3H, $\mathrm{CH}_{3}-\mathrm{C}^{\prime}$ '); 1.67 (s, 3H, H-8'); 1.60 (s, 3H, CH-C3'); ${ }^{13} \mathrm{C}$ NMR: 155.2 (C-3); 154.1 (C-1); 138.6 (C-5); 137.2 (C-3'); 131.8 (C-7'); 123.9 (C-6'); 122.2 (C-2'); 118.1 (C4); 109.7 (C-6); 101.0 (C-2); 39.6 (C-4'); 26.4 (C-5'); 25.6 (C-8'); 25.0 (C-1' '); $20.0\left(\mathrm{CH}_{3}-\mathrm{Ar}\right) ; 17.6\left(\mathrm{CH}_{3}-\mathrm{C}^{\prime}\right)$; $16.1\left(\mathrm{CH}_{3}-\mathrm{C} 3\right.$ '); IR $\left(\mathrm{cm}^{-1}\right)$ : 3393, 2975, 2925 , 2859, 1602; MS (m/z, \%): $\mathrm{M}^{+} 260$ (21.7), 191 (26.9), 177 (13.9), 137 (100), $123(10.5)$.

(E)-2-(3,7-dimethylocta-2,6-dienyl)benzene-1,3,5-triol (geranylphloroglucinol) $\mathbf{1 3}$

To a solution of phloroglucinol $(1.21 \mathrm{~g}, 7.5 \mathrm{mmol})$ and $\mathrm{BF}_{3} \mathrm{OEt}_{2}(1.06$ $\mathrm{g}, 7.5 \mathrm{mmol})$ in freshly distilled 1,4-dioxane $(5 \mathrm{~mL})$, a solution of geranio $(1.15 \mathrm{~g}, 7.5 \mathrm{mmol})$ in 1,4-dioxane $(5 \mathrm{~mL})$ was added dropwise, with stirring at room temperature and under a $\mathrm{N}_{2}$ atmosphere. After the addition was complete, the stirring was continued overnight. When the end of the reaction was verified by TLC, the mixture was poured onto crushed ice (app. $30 \mathrm{~g}$ ) and it was extracted with diethyl ether $(3 \times 30 \mathrm{~mL})$. Then, the ethereal layer was washed with $5 \% \mathrm{NaHCO}_{3}(30 \mathrm{~mL})$, water $(2 \times 20 \mathrm{~mL})$, dried over $\mathrm{Na}_{2} \mathrm{SO}_{4}$, filtered and the solvent was evaporated under reduced pressure. The crude was redissolved in $\mathrm{CH}_{2} \mathrm{Cl}_{2}(5 \mathrm{~mL})$ and the mixture was subjected to silica gel flash column chromatography with petroleum ether/EtOAc mixtures of increasing polarity $(19.8: 0.2 \rightarrow 0.2: 19.8)$ as the mobile phase to afford the compound $\mathbf{1 3}$ as a viscous brownish oil (0.832 g, 4,2 \% yield). ${ }^{1} \mathrm{H}$ NMR: 5.99 (brs, $\left.2 \mathrm{H},-\mathrm{OH}\right)$; $5.93(\mathrm{~s}, 2 \mathrm{H}, \mathrm{H}-4$ and $\mathrm{H}-6) ; 5.22\left(\mathrm{t}, J=6.8 \mathrm{~Hz}, 1 \mathrm{H}, \mathrm{H}-2^{\prime}\right) ; 5.03(\mathrm{t}, J=5.9$ Hz, 1H, H-6'); 3.30 (d, J=6.9 Hz, 2H, H-1'); 208-2.05 (m, 2H, H-5'); 2.03 2.02 (m, 2H, H-4'); 1.76 (s, 3H, $\mathrm{CH}_{3}-\mathrm{C}^{\prime}$ '); 1.66 (s, 3H, H-8'); 1.57 (s, 3H, $\left.\mathrm{CH}_{3}-\mathrm{C} 3{ }^{\prime}\right) ;{ }^{13} \mathrm{C}$ NMR: 155.7 (C-1 and C-3), 154.7 (C-5), 138.7 (C-3'), 131.9 (C-7'), 123.7 (C-6'), 122.0 (C-2'), 106.3 (C-2), 96.1 (C-4 and C-6), 39.6 (C$\left.4^{\prime}\right), 26.3$ (C-5'), 25.6 (C-8'), 21.9 (C-1'), 17.6 ( $\mathrm{CH}_{3}-\mathrm{C}^{\prime}$ '), 16.0 ( $\left.\mathrm{CH}_{3}-\mathrm{C} 3^{\prime}\right)$; IR $\left(\mathrm{cm}^{-1}\right): 3397,2967,2925,1706,1620,1515,1463,1377 ; \mathrm{MS}(\mathrm{m} / \mathrm{z}, \%): \mathrm{M}^{+} 262$ (0.2\%), 191 (100), 175 (52.7), 137 (49.8), 123 (47.8), 69 (22.1).

\section{(E)-2-(3,7-dimethylocta-2,6-dienyl)-1,3,5-trimethoxybenzene 14}

A solution of compound $13(0.36 \mathrm{~g}, 1.4 \mathrm{mmol})$, dimethyl sulphate $(0.58$ $\mathrm{g}, 4.6 \mathrm{mmol})$ and potassium carbonate $(0.58 \mathrm{~g}, 4.2 \mathrm{mmol})$ in dry acetone (50 $\mathrm{mL}$ ) was refluxed for $6 \mathrm{~h}$. in presence of. Later the mixture was filtered, and the inorganic salts washed with acetone $(2 \times 10 \mathrm{~mL})$. The combined acetone solutions were evaporated under reduced pressure, the residue macerated with crushed ice, extracted with ethyl acetate $(2 \times 40 \mathrm{~mL})$. Then, the organic layer was washed with sodium hydroxide solution $(5 \%)$, water, dried under $\mathrm{Na}_{2} \mathrm{SO}$, filtered and the solvent was evaporated under reduced pressure to afford the compound 14 as a brownish oil $(0.42 \mathrm{~g}, 98.5 \%)$. ${ }^{1} \mathrm{H}$ NMR: $6.14(\mathrm{~s}, 2 \mathrm{H}, \mathrm{H}-4$ and H-6); 5.19 (t, $\left.J=6.9 \mathrm{~Hz}, 1 \mathrm{H}, \mathrm{H}-2^{\prime}\right) ; 5.09$ (t, $\left.J=6.3 \mathrm{~Hz}, 1 \mathrm{H}, \mathrm{H}-6^{\prime}\right) ; 3.92$ (s, 3H, $\left.\mathrm{OCH}_{3}\right) ; 3.79\left(\mathrm{~s}, 6 \mathrm{H}, 2 \mathrm{xOC} \underline{\mathrm{H}}_{3}\right) ; 3.29(\mathrm{~d}, J=7.0 \mathrm{~Hz}, 2 \mathrm{H}, \mathrm{H}-1$ ') $) 2.08-2.05(\mathrm{~m}$, 2H, H-5'); 1.99-1.95 (m, 2H, H-4'); 1.78 (s, 3H, CH -C3'); 1.66 (s, 3H, H-8'); 1.59 (s, 3H, $\left.\mathrm{CH}_{3}-\mathrm{C} 7^{\prime}\right)$; ${ }^{13} \mathrm{C}$ NMR: 159.0 (C-5); $158.4(\mathrm{C}-1$ and $\mathrm{C}-3) ; 133.6$ (C-3'); 130.6 (C-7'); 124.3 (C-6'); 123.2 (C-2'); 110.5 (C-2); 90.4 (C-4 and C-6); $55.3\left(2 \mathrm{xOCH}_{3}\right) ; 54.9\left(\mathrm{OCH}_{3}\right) ; 39.6\left(\mathrm{C}-4^{\prime}\right) ; 26.5(\mathrm{C}-5$ ' $) ; 25.3\left(\mathrm{C}-8^{\prime}\right) ; 21.4$ $\left(\mathrm{C}-1\right.$ '); $17.3\left(\mathrm{CH}_{3}-\mathrm{C}^{\prime}\right) ; 15.6\left(\mathrm{CH}_{3}-\mathrm{C}^{\prime}\right)$; IR $\left(\mathrm{cm}^{-1}\right): 2935,2836,1726,1608$, $1596,1496,1455,1437,1417,1377,1322 ; \mathrm{MS}(\mathrm{m} / z, \%): \mathrm{M}^{+} 304$ (10.9\%), 235 (23.8), 181 (100), $167(15.0), 69(12.9)$
(E)-2-(3,7-dimethylocta-2,6-dienyl)-6-methoxyphenol 15, (E)-3-(3,7dimethylocta-2,6-dienyl)-2-methoxyphenol 16 and $(E)-5$-(3,7-dimethylocta2,6-dienyl)-2-methoxyphenol 17.

To a solution of 2-methoxyphenol $(1.50 \mathrm{~g}, 12.1 \mathrm{mmol})$ and $\mathrm{BF}_{3} \cdot \mathrm{OEt}_{2}(2.25$ $\mathrm{g}, 15.8 \mathrm{mmol})$ in freshly distilled 1,4-dioxane $(5 \mathrm{~mL})$ was added dropwise, with stirring at room temperature and under a $\mathrm{N}_{2}$ atmosphere, a solution of geraniol $(2.44 \mathrm{~g}, 15.8 \mathrm{mmol})$ in 1,4-dioxane $(5 \mathrm{~mL})$. After the addition was complete, the stirring was continued overnight. When the end of the reaction was verified by TLC, the mixture was poured onto crushed ice (app. $30 \mathrm{~g}$ ) and it was extracted with diethyl ether $(3 \times 30 \mathrm{~mL})$. Then, the ethereal layer was washed with $5 \% \mathrm{NaHCO}_{3}(30 \mathrm{~mL})$, water $(2 \times 20 \mathrm{~mL})$, dried over $\mathrm{Na}_{2} \mathrm{SO}_{4}$, filtered and the solvent was evaporated under reduced pressure. The crude was redissolved in $\mathrm{CH}_{2} \mathrm{Cl}_{2}(5 \mathrm{~mL})$ and the mixture was subjected to silica gel flash column chromatography with petroleum ether/EtOAc mixtures of increasing polarity $(19.8: 0.2 \rightarrow 0.2: 19.8)$ as the mobile phase. Three fractions were obtained. Fraction I: compound 15 as a yellow oil $(0.09 \mathrm{~g}, 2.5 \%) .{ }^{1} \mathrm{H}$ NMR: 6.81-6.74 (m, 3H, H-3, H-4 and H-5); $5.72(\mathrm{~s}, 1 \mathrm{H}, \mathrm{OH}) ; 5.37(\mathrm{t}, J=$ $\left.7,2 \mathrm{~Hz}, 1 \mathrm{H}, \mathrm{H}-2^{\prime}\right) ; 5.13$ (t, $J=6.6 \mathrm{~Hz}, 1 \mathrm{H}, \mathrm{H}-6$ '); $3.90\left(\mathrm{~s}, 3 \mathrm{H}, \mathrm{OCH}_{3}\right) ; 3.39$ (d, $J$ $\left.=7.2 \mathrm{~Hz}, 2 \mathrm{H}, \mathrm{H}-1^{\prime}\right) ; 2.14-2.11\left(\mathrm{~m}, 2 \mathrm{H}, \mathrm{H}-5^{\prime}\right) ; 2.09-2.05\left(\mathrm{~m}, 2 \mathrm{H}, \mathrm{H}^{3} 4^{\prime}\right) ; 1.74(\mathrm{~s}$, $3 \mathrm{H}, \mathrm{CH}_{3}-\mathrm{C} 3^{\prime}$ ); 1.70 (s, 3H, H-8'); 1.62 (s, 3H, CH $-\mathrm{C} 7{ }^{\prime}$ ); ${ }^{13} \mathrm{C}^{\mathrm{N} M R}$ : 146.3 (C6); 143.4 (C-1); 136.3 (C-3'); 131.4 (C-7'); 127.5 (C-2); 124.4 (C-6'); 122.1 (C-2'); 121.8 (C-3); 119.2 (C-4); $108.3(\mathrm{C}-5)$; $56.0\left(\mathrm{OCH}^{\prime}\right) ; 39.8\left(\mathrm{C}-4^{\prime}\right) ; 27.8$ (C-1'); 26.6 (C-5'); 25.7 (C-8'); 17.7 ( $\mathrm{CH}_{3}-\mathrm{C}^{\prime}$ '); 16.0 ( $\left.\mathrm{CH}_{3}-\mathrm{C} 3^{\prime}\right)$; IR ( $\left.\mathrm{cm}^{-1}\right)$ : $3545,2964,2923,2853,1616,1592,1478,1442,1376,1356,1270,1217$; MS $(\mathrm{m} / \mathrm{z}, \%): \mathrm{M}^{+} 260(53.8 \%), 191(29.4), 137$ (100), 123 (78.7), 69 (36.7) Fraction II: compound 16 as aviscous yellow oil $(0.12 \mathrm{~g}, 4.1 \%)$; ${ }^{1} \mathrm{H}$ NMR: 6.83 (d, $J=$ $8.5 \mathrm{~Hz}, 1 \mathrm{H}, \mathrm{H}-6) ; 6.68$ (d, $J=6.8 \mathrm{~Hz}, 2 \mathrm{H}, \mathrm{H}-4$ and $\mathrm{H}-5) ; 5.47$ (s, 1H, OH); 5.33 $\left(\mathrm{t}, J=7.2 \mathrm{~Hz}, 1 \mathrm{H}, \mathrm{H}-2^{\prime}\right) ; 5.12\left(\mathrm{t}, J=6.4 \mathrm{~Hz}, 1 \mathrm{H}, \mathrm{H}-6\right.$ ') $3.87\left(\mathrm{~s}, 3 \mathrm{H}, \mathrm{OCH}_{3}\right) ; 3.29$ (d, $J=7.2 \mathrm{~Hz}, 2 \mathrm{H}, \mathrm{H}-1^{\prime}$ ); 2.13-2.10 (m, 2H, H-5'); 2.07-2.06 (m, 2H, H-4'); 1.17 (s, 3H, $\mathrm{CH}_{3}-\mathrm{C}^{\prime}$ '); 1.68 (s, 3H, H-8'); 1.60 (s, 3H, $\mathrm{CH}_{3}-\mathrm{C}^{\prime}$ '); ${ }^{13} \mathrm{C} \mathrm{NMR}^{2}$ 146.4 (C-2); 143.6 (C-1); 136.0 (C-3'); 133.7 (C-3); 131.4 (C-7'); 124.2 (C6'); 123.4 (C-2'); 120.8 (C-5); 114.2 (C-6); 110.8 (C-4); $55.8\left(\mathrm{OCH}_{3}\right) ; 39.7$ (C4'); 33.8 (C-1'); 26.7 (C-5'); 25.7 (C-8'); 17.7 (C-10'); 16.1 (C-9'); IR (cm $\left.{ }^{-1}\right)$ : 3443, 2963, 2924, 2853, 1676, 1600, 1512, 1451, 1432, 1376, 1267, 1230; MS $(\mathrm{m} / \mathrm{z}, \%): \mathrm{M}^{+} 260(84.3 \%), 159(100), 137$ (89.9), $123(42.0), 69$ (40.4) Fraction III: compound 17 as aviscous yellow oil $(0.01 \mathrm{~g}, 0.3 \%)$; ${ }^{1} \mathrm{H}$ NMR: 6.78 (d, $J=8.3 \mathrm{~Hz}, 1 \mathrm{H}, \mathrm{H}-3) ; 6.76(\mathrm{~d}, J=1.7 \mathrm{~Hz}, 1 \mathrm{H}, \mathrm{H}-6) ; 6.66(\mathrm{dd}, J=8.3-1.7 \mathrm{~Hz}$, $1 \mathrm{H}, \mathrm{H}-4) ; 5.55$ (s, $1 \mathrm{H}, \mathrm{OH}) ; 5.31$ (t, $J=7.2 \mathrm{~Hz}, 1 \mathrm{H}, \mathrm{H}-2$ '); 5.10 (t, $J=6.7 \mathrm{~Hz}$, $\left.1 \mathrm{H}, \mathrm{H}-6^{\prime}\right) ; 3.86\left(\mathrm{~s}, 3 \mathrm{H}, \mathrm{OCH}_{3}\right) ; 3.26(\mathrm{~d}, J=7.2 \mathrm{~Hz}, 2 \mathrm{H}, \mathrm{H}-1$ ' $) ; 2.12-2.08(\mathrm{~m}$, 2H, H-5'); 2.05-2.03 (m, 2H, H-4'); 1.69 (s, 6H, $\mathrm{CH}_{3}-\mathrm{C} 3$ ' and $\mathrm{H}-8^{\prime}$ '); 1.60 (s, $3 \mathrm{H}, \mathrm{CH}_{3}-\mathrm{C}^{\prime}$ ); ${ }^{13} \mathrm{C}$ NMR: 145.5 (C-1); 144.7 (C-2); 136.0 (C-3'); 135.2 (C5); 131.4 (C-7'); 124.3 (C-6'); 123.2 (C-2'); 119.5 (C-4); 114.6 (C-6); 110.6 (C-3); $56.0\left(\mathrm{OC}_{3}\right)$; 39.7 (C-4'); 33.5 (C-1'); 26.6 (C-5'); 25.7 (C-8'); 17.7 $\left(\mathrm{CH}_{3}-\mathrm{C}^{\prime}\right)$; $16.1\left(\mathrm{CH}_{3}-\mathrm{C} 3\right.$ ') ; IR $\left(\mathrm{cm}^{-1}\right): 3443,2923,2853,1591,1509,1442$, $1377,1270,1212,1128$.

\section{(E)-4-(3,7-dimethylocta-2,6-dienyl)benzene-1,3-diol 18}

To a solution of resorcinol $(1.00 \mathrm{~g}, 9.1 \mathrm{mmol})$ and $\mathrm{BF}_{3} \cdot \mathrm{OEt}_{2}(1.29 \mathrm{~g}$, $9.1 \mathrm{mmol})$ in freshly distilled 1,4-dioxane $(5 \mathrm{~mL})$ was added dropwise, with stirring at room temperature and under a $\mathrm{N}_{2}$ atmosphere, a solution of geraniol $(2.80 \mathrm{~g}, 18.1 \mathrm{mmol})$ in 1,4-dioxane $(5 \mathrm{~mL})$. After the addition was complete, the stirring was continued overnight. When the end of the reaction was verified by TLC, the mixture was poured onto crushed ice (app. $30 \mathrm{~g}$ ) and it was extracted with diethyl ether $(3 \times 30 \mathrm{~mL})$. Then, the ethereal layer was washed with $5 \% \mathrm{NaHCO}_{3}(30 \mathrm{~mL})$, water $(2 \times 20 \mathrm{~mL})$, dried over $\mathrm{Na}_{2} \mathrm{SO}_{4}$, filtered and the solvent was evaporated under reduced pressure. The crude was redissolved in $\mathrm{CH}_{2} \mathrm{Cl}_{2}(5 \mathrm{~mL})$ and the mixture was subjected to silica gel flash column chromatography with petroleum ether/EtOAc mixtures of increasing polarity $(19.8: 0.2 \rightarrow 0.2: 19.8)$ as the mobile phase to afford the compound $\mathbf{1 8}$ as a viscous yellow oil $(0.268 \mathrm{~g}, 11.9 \%)$; ${ }^{1} \mathrm{H}$ NMR: 6.92 (d, $\left.J=8.8 \mathrm{~Hz}, 1 \mathrm{H}, \mathrm{H}-5\right)$; $6.37(\mathrm{~d}, J=2.4 \mathrm{~Hz}, 1 \mathrm{H}, \mathrm{H}-2) ; 6.36(\mathrm{dd}, J=2.4$ and $8.8 \mathrm{~Hz}, 1 \mathrm{H}, \mathrm{H}-6) ; 5.30(\mathrm{t}, J=$ $7.0 \mathrm{~Hz}, 1 \mathrm{H}, \mathrm{H}-2^{\prime}$ ); 5.09 (t, $J=6.1 \mathrm{~Hz}, 1 \mathrm{H}, \mathrm{H}-6$ '); 3.27 (d, J=7.0Hz, 2H, H-1'); 2.12-2.09 (m, 2H, H-5'); 2.08-2.06 (m, 2H, H-4'); 1.72 (s, 3H, CH -C3'); 1.69 (s, 3H, H-8'); 1.60 (s, 3H, CH $\left.-\mathrm{C}^{\prime}\right) ;{ }^{13} \mathrm{C}$ NMR: $154.8\left({ }^{*} \mathrm{C}-1\right) ; 154.7\left({ }^{*} \mathrm{C}-3\right)$; 137.6 (C-3'); 131.7 (C-7'); 130.3 (C-5); 124.0 (C-6'); 122.1 (C-2’); 119.4 (C4); 107.6 (C-6); 103.2 (C-2); 39.6 (C-4'); 28.3 (C-1'); 26.4 (C-5'); 25.6 (C-8'); $17.6\left(\mathrm{CH}_{3}-\mathrm{C}^{\prime}\right) ; 16.0\left(\mathrm{CH}_{3}-\mathrm{C} 3{ }^{\prime}\right) ; \mathrm{IR}\left(\mathrm{cm}^{-1}\right): 3387,2927,1702,1620,1508$, 1455, 1377, 1297, 1152; MS (m/z, \%): $\mathrm{M}^{+} 246$ (16.8\%), 177 (43.5), 161 (28.5), $123(100), 69(29.0) *$ interchangeable signs.

\section{(E)-3-(3,7-dimethylocta-2,6-dienyl)benzene-1,2-diol 19}

To a solution of pyrocatechol $(1.00 \mathrm{~g}, 9.1 \mathrm{mmol})$ and $\mathrm{BF}_{3} \mathrm{OEt}_{2}(1.3 \mathrm{~g}$, $9.1 \mathrm{mmol})$ in freshly distilled 1,4-dioxane $(5 \mathrm{~mL})$ was added dropwise, with 
stirring at room temperature and under a $\mathrm{N}_{2}$ atmosphere, a solution of geraniol $(1.4 \mathrm{~g}, 9.1 \mathrm{mmol})$ in 1,4-dioxane $(5 \mathrm{~mL})$. After the addition was complete, the stirring was continued overnight. When the end of the reaction was verified by TLC, the mixture was poured onto crushed ice (app. $30 \mathrm{~g}$ ) and it was extracted with diethyl ether $(3 \times 30 \mathrm{~mL})$. Then, the ethereal layer was washed with $5 \% \mathrm{NaHCO}_{3}(30 \mathrm{~mL})$, water $(2 \times 20 \mathrm{~mL})$, dried over $\mathrm{Na}_{2} \mathrm{SO}_{4}$, filtered and the solvent was evaporated under reduced pressure. The crude was redissolved in $\mathrm{CH}_{2} \mathrm{Cl}_{2}(5 \mathrm{~mL})$ and the mixture was subjected to silica gel flash column chromatography with petroleum ether/EtOAc mixtures of increasing polarity $(19.8: 0.2 \rightarrow 0.2: 19.8)$ as the mobile phase to afford the compound $\mathbf{1 9}$ as a viscous brown oil $(0.108 \mathrm{~g}, 4.8 \%) ;{ }^{1} \mathrm{H}$ NMR: 6.79-6.72 (m, $2 \mathrm{H}, \mathrm{H}-5$ and $\mathrm{H}-6) ; 6.66(\mathrm{~d}, J=7.0 \mathrm{~Hz}, 1 \mathrm{H}, \mathrm{H}-4) ; 5.38(\mathrm{~s}, 1 \mathrm{H}, \mathrm{OH}) ; 5.33-5.31(\mathrm{~m}, 2 \mathrm{H}, \mathrm{OH}$ and $\left.\mathrm{H}-2^{\prime}\right) ; 5.05-5.04\left(\mathrm{~m}, 1 \mathrm{H}, \mathrm{H}-6^{\prime}\right) ; 3.37$ (d, $J=7.1 \mathrm{~Hz}, 2 \mathrm{H}, \mathrm{H}-1$ '); $2.14-2.12$ (m, 2H, H-5'); 2.11-2.09 (m, 2H, H-4'); 1.78 (s, 3H, $\mathrm{CH}_{3}-\mathrm{C}^{\prime}$ ); 1.69 (s, 3H, H-8'); 1.60 (s, 3H, CH -C7'); ${ }^{13} \mathrm{C}_{\mathrm{NMR}} 144.3$ (C-1);141.9 (C-2); 138.9 (C3'); 132.2 (C-7'); 127.4 (C-3); 123.7 (C-6'); 121.7 (C-2'); 121.4 (C-4); 120.7 (C-5); 113.2 (C-6); 39.6 (C-4'); 29.9 (C-1'); 26.3 (C-5'); 25.7 (C-8'); 17.7 $\left(\mathrm{CH}_{3}-\mathrm{C}^{\prime}\right) ; 16.1\left(\mathrm{CH}_{3}-\mathrm{C}^{\prime}\right)$; IR $\left(\mathrm{cm}^{-1}\right): 3588,3418,2967,2922,2845,1620$, $1595,1475,1375,1278$.

(E)-4-(3,7-dimethylocta-2,6-dienyl)-5-isopropyl-2-methylphenol 20

To a solution of carvacrol $(0.25 \mathrm{~g}, 1.67 \mathrm{mmol})$ and $\mathrm{BF}_{3} \mathrm{Et}_{2} \mathrm{O}(0.2 \mathrm{~mL}, 1.59$ $\mathrm{mmol})$ in freshly distilled ethyl ether $(10 \mathrm{~mL})$ a solution of geraniol $(0.308 \mathrm{~g}$, $2.00 \mathrm{mmol}$ ) in ethyl ether $(5 \mathrm{~mL})$ was added dropwise with stirring at room temperature and under a $\mathrm{N}_{2}$ atmosphere. After the addition was complete, the stirring was continued overnight. When the end of the reaction was verified by TLC, the mixture was poured onto crushed ice (app. $30 \mathrm{~g}$ ) and it was extracted with ethyl acetate $(3 \times 20 \mathrm{~mL})$. Then, the organic layer was washed with $5 \%$ $\mathrm{NaHCO}_{3}(30 \mathrm{~mL})$, water $(2 \times 20 \mathrm{~mL})$, dried over $\mathrm{Na}_{2} \mathrm{SO}_{4}$, filtered and the solvent was evaporated under reduced pressure. The crude was redissolved in $\mathrm{CH}_{2} \mathrm{Cl}_{2}(5 \mathrm{~mL})$ and the mixture was subjected to silica gel flash column chromatography with petroleum ether/ethyl acetate mixtures of increasing polarity as the mobile phase to afford the compound $\mathbf{2 0}$ as a dark yellow viscous oil (86.6 mg, 21.7\%); ${ }^{1} \mathrm{H}$ NMR: 6.88 (s, $\left.1 \mathrm{H}, \mathrm{H}-3\right)$; 6.69 (s, $\left.1 \mathrm{H}, \mathrm{H}-6\right)$; $5.20\left(\mathrm{t}, J=6.9 \mathrm{~Hz}, 1 \mathrm{H}, \mathrm{H}-2^{\prime}\right) ; 5.10\left(\mathrm{t}, J=6.7 \mathrm{~Hz}, 1 \mathrm{H}, \mathrm{H}-6{ }^{\prime}\right) ; 4.49(\mathrm{~s}, 1 \mathrm{H}, \mathrm{OH})$; 3.27 (d, $J=6.8 \mathrm{~Hz}, 2 \mathrm{H}, \mathrm{H}-1^{\prime}$ ); 3.08 (sext. $\left.J=6.8 \mathrm{~Hz}, 1 \mathrm{H} \mathrm{C} \underline{\mathrm{H}}\left(\mathrm{CH}_{3}\right)_{2}\right) ; 2.19$ (s, $\left.3 \mathrm{H}, \mathrm{CH}_{3}-\mathrm{Ar}\right) ; 2.19-2.08\left(\mathrm{~m}, 2 \mathrm{H}, \mathrm{H}-5^{\prime}\right) ; 2.06-2.02\left(\mathrm{~m}, 2 \mathrm{H}, \mathrm{H}-4^{\prime}\right) ; 1.71(\mathrm{~s}, 3 \mathrm{H}$, $\mathrm{CH}_{3}-\mathrm{C}^{3}$ ); 1.67 (s, $\left.3 \mathrm{H}, \mathrm{H}-8^{\prime}\right) ; 1.59$ (s, 3H, $\mathrm{CH}_{3}-\mathrm{C}^{\prime}$ ); 1.19 (d, $J=6.8 \mathrm{~Hz}, 6 \mathrm{H}$, $\left.\left(\mathrm{CH}{ }_{3}\right)_{2} \mathrm{CH}\right) ;{ }^{13} \mathrm{C}$ NMR: 152.4 (C-1); 146.1 (C-5); 135.3 (C-3'); 131.9 (C-3); 130.8 (C-4); 124.6 (C-7'); 124.3 (C-6'); 124.1 (C-2'); 111.8 (C-6); 39.7 (C-4');

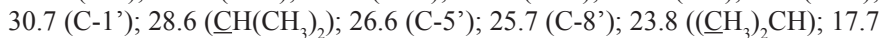
( $\left.\mathrm{CH}_{3}-\mathrm{C}^{\prime}\right) ; 16.2\left(\mathrm{CH}_{3}-\mathrm{C}^{\prime}\right)$ ); $15.2\left(\mathrm{CH}_{3}-\mathrm{Ar}\right) ; \mathrm{IR}\left(\mathrm{cm}^{-1}\right)$ : 3398, 3418, 2962, 2925 , $2845,1620,1589,1496,1456,1380,1278,1107,889,813 ; \mathrm{MS}(\mathrm{m} / \mathrm{z}, \%): \mathrm{M}^{+}$ 285 (81\%), 257 (14.9), 256 (22.3), 255 (14), 191 (13.5), 177 (100), 163 (40).

(E)-2-(3,7-dimethylocta-2,6-dienyl)-4-isopropyl-3-methylphenol 21 and (E)-2-(3,7-dimethylocta-2,6-dienyl)-4-isopropyl-5-methylphenol 22

To a solution of 4-isopropyl-3-methylphenol $(0.25 \mathrm{~g}, 1.67 \mathrm{mmol})$ and $\mathrm{BF}_{3} \mathrm{Et}_{2} \mathrm{O}(0.2 \mathrm{~mL}, 1.59 \mathrm{mmol})$ in freshly distilled ethyl ether $(10 \mathrm{~mL})$ was added dropwise with stirring at room temperature and under a $\mathrm{N}_{2}$ atmosphere, a solution of geraniol $(0.308 \mathrm{~g}, 2.00 \mathrm{mmol})$ in ethyl ether $(5 \mathrm{~mL})$. After the addition was complete, the stirring was continued overnight. When the finish of the reaction was verified by TLC, the mixture was poured onto crushed ice (app. $30 \mathrm{~g}$ ) and it was extracted with ethyl acetate $(3 \times 20 \mathrm{~mL})$. Then, the organic layer was washed with $5 \% \mathrm{NaHCO}_{3}(30 \mathrm{~mL})$, water $(2 \times 20 \mathrm{~mL})$, dried over $\mathrm{Na}_{2} \mathrm{SO}_{4}$, filtered and the solvent was evaporated under reduced pressure. The crude was redissolved in $\mathrm{CH}_{2} \mathrm{Cl}_{2}(5 \mathrm{~mL})$ and the mixture was subjected to silica gel flash column chromatography with petroleum ether/EtOAc mixtures of increasing polarity $(19.8: 0.2 \rightarrow 15.2: 4.8)$ as the mobile phase to obtain two fractions: Fraction I: compound $\mathbf{2 1}$ as a yellow viscous oil (67.5 mg,4.2\%); ${ }^{1} \mathrm{H}$ NMR: 7.01 (d, $\left.J=8.4 \mathrm{~Hz}, 1 \mathrm{H}, \mathrm{H}-5\right) ; 6.67$ (d, $\left.J=8.4 \mathrm{~Hz}, 1 \mathrm{H}, \mathrm{H}-6\right) ; 5.13$ (t, $\left.J=6.6 \mathrm{~Hz}, 1 \mathrm{H}, \mathrm{H}-2^{\prime}\right) ; 5.04\left(\mathrm{t}, J=5.6 \mathrm{~Hz}, 1 \mathrm{H}, \mathrm{H}-6^{\prime}\right) ; 4.78(\mathrm{~s}, 1 \mathrm{H}, \mathrm{OH})$; 3.41 (d, $\left.J=6.6 \mathrm{~Hz}, 2 \mathrm{H}, \mathrm{H}-1^{\prime}\right) ; 3.13$ (sept. $\left.J=6.8 \mathrm{~Hz}, 1 \mathrm{H} \mathrm{C} \underline{\mathrm{H}}\left(\mathrm{CH}_{3}\right)_{2}\right) ; 2.26$ (s, 3H, CH-Ar); 2.09-2.06 (m, 2H, H-5'); 2.04-2.02 (m, 2H, H-4'); $1.80(\mathrm{~s}$, $\left.3 \mathrm{H}, \mathrm{CH}_{3}-\mathrm{C}^{\prime}\right) ; 1.66\left(\mathrm{~s}, 3 \mathrm{H}, \mathrm{H}-8^{\prime}\right) ; 1.58\left(\mathrm{~s}, 3 \mathrm{H}, \mathrm{CH}_{3}-\mathrm{C}^{\prime}\right) ; 1.20(\mathrm{~d}, J=6.8 \mathrm{~Hz}$, $\left.6 \mathrm{H},\left(\mathrm{CH}_{3}\right)_{2} \mathrm{CH}\right) ;{ }^{13} \mathrm{C}$ NMR: $151.9(\mathrm{C}-1)$; 139.3 (C-4); 137.0 (C-3'); 131.7 (C3); 129.7 (C-7'); 125.9 (C-2); 124.0 (C-5'); 123.3 (C-6'); 122.1 (C-2'); 114.6 (C-6); 39.7 (C-4'); $29.3\left(\mathrm{CH}\left(\mathrm{CH}_{3}\right)_{2}\right) ; 26.5\left(\mathrm{C}-5^{\prime}\right) ; 26.1(\mathrm{C}-1$ '); 25.7 (C-8'); 23.6 $\left(\left(\mathrm{CH}_{3}\right)_{2} \mathrm{CH}\right) ; 17.7\left(\mathrm{CH}_{3}-\mathrm{C}^{\prime}\right) ; 16.2\left(\mathrm{CH}_{3}-\mathrm{C}^{\prime}\right) ; 14.7\left(\mathrm{CH}_{3}-\mathrm{Ar}\right) ; \mathrm{IR}\left(\mathrm{cm}^{-1}\right): 3421$, 2962, 2926, 1617, 1495, 1452, 1380, 1277, 1149, 1107, 1039, 888, 811; MS $(\mathrm{m} / z, \%): \mathrm{M}^{+} 285$ (38\%), 194 (68), 191 (13.5), 177 (100), 163 (40). Fraction II: isomers 21/22 mixture as dark yellow viscous oil (0.102 g, 21.6\%) Compound 22: 'H NMR: 6.96 (s, 1H, H-3); 6.62 (s, 1H, H-6); 5.35 (t, $\left.J=7.0 \mathrm{~Hz}, 1 \mathrm{H}, \mathrm{H}-2^{\prime}\right)$;
5.17-5.07 (m, 1H, H-6'); 5.04 (s, 1H, OH); 3.35 (d, $J=7.0 \mathrm{~Hz}, 2 \mathrm{H}, \mathrm{H}-1^{\prime}$ ); 3.06 (sept. $\left.J=6.8 \mathrm{~Hz}, 1 \mathrm{H} \mathrm{C} \underline{\mathrm{H}}\left(\mathrm{CH}_{3}\right)_{2}\right) ; 2.27$ (s, $\left.3 \mathrm{H}, \mathrm{CH}_{3}-\mathrm{Ar}\right) ; 2.14-2.08(\mathrm{~m}, 2 \mathrm{H}$ H-5'); 2.05-2.04 (m, 2H, H-4'); 1.79 (s, 3H, $\mathrm{CH}_{3}-\mathrm{C}^{\prime}$ '); 1.70 (s, 3H, H-8'); $1.61\left(\mathrm{~s}, 3 \mathrm{H}, \mathrm{CH}_{3}-\mathrm{C}^{\prime}\right) ; 1.25\left(\mathrm{~d}, J=6.8 \mathrm{~Hz}, 6 \mathrm{H},\left(\mathrm{CH}_{3}\right) \mathrm{CH}\right) ;{ }^{13} \mathrm{C} \mathrm{NMR}: 151.9$ (C-1); 138.9 (C-4); 138.1 (C-3'); 131.6 (C-7'); 126.3 (C-3); 126.0 (C-5); 124.0 (C-6'); 123.8 (C-2); 122.2 (C-2'); 117.5 (C-6); 39.7 (C-4'); 29.9 (C-1'); 28.6 $\left.\left(\underline{\mathrm{CH}}\left(\mathrm{CH}_{3}\right)_{2}\right) ; 26.5\left(\mathrm{C}^{\prime}\right)^{\prime}\right) ; 25.6\left(\mathrm{C}-8^{\prime}\right) ; 23.5\left(\left(\mathrm{CH}_{3}\right)_{2} \mathrm{CH}\right) ; 18.8\left(\mathrm{CH}_{3}-\mathrm{Ar}\right) ; 17.6$ $\left(\underline{\mathrm{C}} \mathrm{H}_{3}-\mathrm{C} 7^{\prime}\right) ; 16.2\left(\mathrm{CH}_{3}-\mathrm{C} 3^{\prime}\right)$.

(E)-2-tert-butyl-4-(3,7-dimethylocta-2,6-dienyl)-5-methylphenol 23

To a solution of 2-tert-butyl-5-methylphenol $(0.25 \mathrm{~g}, 1.52 \mathrm{mmol})$ and $\mathrm{BF}$ $\mathrm{Et}_{2} \mathrm{O}(0.2 \mathrm{~mL}, 1.59 \mathrm{mmol})$ in freshly distilled ethyl ether $(10 \mathrm{~mL})$ a solution of geraniol $(0.308 \mathrm{~g}, 2.00 \mathrm{mmol})$ in ethyl ether $(5 \mathrm{~mL})$ was added dropwise with stirring at room temperature and under a $\mathrm{N}_{2}$ atmosphere,. After the addition was complete, the stirring was continued overnight. When the end of the reaction was verified by TLC, the mixture was poured onto crushed ice (app. $30 \mathrm{~g}$ ) and it was extracted with ethyl acetate $(3 \times 20 \mathrm{~mL})$. Then, the organic layer was washed with $5 \% \mathrm{NaHCO}_{3}(30 \mathrm{~mL})$, water $(2 \times 20 \mathrm{~mL})$, dried over $\mathrm{Na}_{2} \mathrm{SO}_{4}$, filtered and the solvent was evaporated under reduced pressure. The crude was redissolved in $\mathrm{CH}_{2} \mathrm{Cl}_{2}(5 \mathrm{~mL})$ and the mixture was subjected to silica gel flash column chromatography with petroleum ether/ethyl acetate mixtures of increasing polarity as the mobile phase to afford the compound $\mathbf{2 3}$ as a brown viscous oil (123.4 mg, , 17.7\%) ${ }^{1} \mathrm{H}$ NMR: 7.03 (s, 1H, H-3); 6.48 (s, 1H, H-6); $5.23\left(\mathrm{t}, J=7.0 \mathrm{~Hz}, 1 \mathrm{H}, \mathrm{H}-2^{\prime}\right) ; 5.10(\mathrm{t}, J=6.3 \mathrm{~Hz}, 1 \mathrm{H}, \mathrm{H}-6$ '); $4.59(\mathrm{~s}, 1 \mathrm{H}, \mathrm{OH})$; $3.23\left(\mathrm{~d}, J=7.0 \mathrm{~Hz}, 2 \mathrm{H}, \mathrm{H}-1^{\prime}\right) ; 2.18$ (s, 3H, $\left.\mathrm{CH}_{3}-\mathrm{Ar}\right) ; 2.11-2.08$ (m, $2 \mathrm{H}, \mathrm{H}-5$ '); 2.05-2.02 (m, 2H, H-4'); 1.71 (s, 3H, $\mathrm{CH}_{3}-\mathrm{C}^{\prime}$ ) ; 1.67 (s, 3H, H-8'); 1.60 (s, 3H, $\mathrm{CH}_{3}-\mathrm{C}^{\prime}$ ); 1.39 (s, 9H, $\left.\left(\mathrm{CH}_{3}\right)_{3} \mathrm{C}\right) ;{ }^{13} \mathrm{C}$ NMR:152.0 (C-1); 135.5 (C-3'); 134.8 (C-4); 133.2 (C-2); 131.6 (C-7' + C-5); 127.5 (C-3); 124.3 (C-6'); 123.2 (C-2); 118.3 (C-6); 39.7 (C-4'); $34.2\left(\underline{\mathrm{C}}\left(\mathrm{CH}_{3}\right)_{3}\right) ; 31.6\left(\mathrm{C}-1\right.$ '); $29.7\left(\left(\underline{\mathrm{CH}}_{3}\right)_{3} \mathrm{C}\right) ; 26.8$ (C-5'); 25.7 (C-8'); $18.6\left(\mathrm{CH}_{3}-\mathrm{Ar}\right) ; 17.7$ ( $\left.\mathrm{CH}_{3}-\mathrm{C}^{\prime}\right) ; 16.1\left(\underline{\mathrm{CH}}_{3}-\mathrm{C}^{\prime}\right)$ IR $\left(\mathrm{cm}^{-}\right.$ $\left.{ }^{1}\right): 3526,2958,2916,2862,1618,1576,1514,1483,1449,1410,1389,1295$, $1182,1136,1080,949,808$; MS $(\mathrm{m} / z, \%): \mathrm{M}^{+} 300(87.5 \%), 206(41.6), 192$ (100), $163(75), 57(25)$

\section{CONCLUSIONS}

In summary we have prepared fourteen compounds, the known geranylhydroquinone $\mathbf{2}$, geranylorcinol $\mathbf{4}$ and the derivative geranylorcinol 5 and the new geranylphenol derivatives 13-23. All these compounds were obtained by direct geranylation reactions using $\mathrm{BF}_{3} \cdot \mathrm{Et}_{2} \mathrm{O}$ as a catalyst between geraniol and commercially available activated phenols hydroquinone, orcinol, phloroglucinol, guaiacol, resorcinol, catechol, pyrocatechol, carvacrol, 4-isopropyl-3-methylphenol and 2-tert-butyl-5-methylphenol. Additionally, all the synthesized compounds were fully characterized by spectroscopic data, especially by NMR techniques.

On the other hand, the orientation in electrophilic aromatic substitution of geranyl chain was directed in ortho and/or para position according to the location the $\mathrm{OH}$ or $\mathrm{OCH}_{3}$ groups in the aromatic system. Also, for the same reason, mixtures of regio-isomers were obtained in some cases. The low yields were observed due to that during the reaction time, part of geraniol was transformated into unidentified products and unreacted starting material (arenes nuclei) was recovered.

We are currently investigating the effect of a second catalyst in the geranylation reactions and we have found better results in yields for these reactions. These results, together with biological activity assay against plant pathogens will be informed soon.

\section{ACKNOWLEDGEMENTS}

The authors thank to the Centro Cientifico - Tecnológico de Valparaiso (CCTVal, Proyecto BASAL FB/08/21, int. cod. FB/30LE/10) and Dirección General de Investigación y Postgrado (DGIP) of the Universidad Técnica Federico Santa María (PIIC QUI-2011 for L. T., grant $N^{\circ} 13.11 .36$, PAC 2009-2012 for M.O., PAC 2011-2012 for A.M. and PIA for M.C.) for financial support.

\section{REFERENCES}

1. H. C. Lin, and W. L. Chang, Chin. Pharm. J. 43, 11, (1991)

2. G. D. Manners and L. Jurd, J. Chem. Soc. Perkin. Tras. 1, 405, (1977)

3. G. Reynolds and E. Rodriguez, Phytochem. 18, 1567, (1979)

4. G. Reynolds, W. L. Epstein, D. Terry, E. Rodríguez, Contact Dermatitis 6, 272, (1980) 
5. G. Reynolds and E. Rodríguez, Planta Medica, 43, 187, (1981)

6. A. F. Benslimane, Y. F. Pouchus, J. Le Boterff, J. F. Verbist, J. Nat. Prod. 51, 582, (1988)

7. A. Sato, T. Shindo, N. Kasanuki, K. Hasegawa, J. Nat. Prod. 52, 975, (1989)

8. W. Fenical, "4th Proceeding of Food Drugs from the Sea." Marine Technological Society: Washington D.C., 1974.

9. S. De Rosa, A. De Giulio, C. Iodice, J. Nat. Prod. 57, 1711, (1994)

10. G. Rudali, Seances Soc. Biol. Ses Fil. 160, 1365 (1966)

11. G. Rudali, L. Menetrier, Therapie, 22, 895, (1967)

12. L. K. Shubina, S. N. Fedorov, O. S. Radchenko, N. N. Balaneva, S. A. Kolesnikova, P. S. Dmitrenok, A. B. Zigang-Dong, V. A. Stonik, Tetrahedron Lett. 46, 559, (2005)
13. S. N. Fedorov, O. S. Radchenko, L. K. Shubina, N. N. Balaneva, A.M. Bode, V. A. Stonik, Z. Dong, Pharmaceutical Research, 23, 70, (2006)

14. H. N. Eisohly, C. E. Turner, C. A. M. Mahmoud, M. A. Eisohly, Journal Pharmaceutical Science, 71, 1319, (1982)

15. G. Manners, L. Jurd, K. Stevenst, Tetrahedron, 28, 2949, (1972)

16. L. F. Yamaguchi, J. H. G. Lago, T. M. Tanizaki, P. Di Mascio, M. J. Kato, Phytochem. 67, 1838, (2006)

17. E. Rodriguez, P. Hedin; ACS Symposium Series Vol. 208; American Chemical Society: Washington, DC, 1983, Chapter 17, 291-303.

18. E. Baeza, K. Catalán, H. Peña-Cortés, L. Espinoza, J. Villena, H. Carrasco, Quim. Nova, 35, 523, (2012)

19. E. Baeza, K. Catalán, J. Villena, H. Carrasco, M. Cuellar, and L. Espinoza, J. Chil. Chem. Soc. 57, 1219, (2012) 